\title{
Hemoglobin Subunit Delta
}

National Cancer Institute

\section{Source}

National Cancer Institute. Hemoglobin Subunit Delta. NCI Thesaurus. Code C84980.

Hemog lobin subunit delta (147 aa, $\sim 16 \mathrm{kDa}$ ) is encoded by the human HBD gene. This protein plays a role in the transport of oxygen to tissues of the adult body. 